Balázs Gyenge, János Buresch

\title{
2.3 USING A SATISFACTION INDEX SYSTEM IN CORPORATE MANAGEMENT
}

\author{
"The lack of dissatisfaction \\ does not equal satisfaction."
}

\begin{abstract}
Summary: According to market economy interpretation, the key to make a profit originates from income from customers; therefore, the companies' management can evaluate their basic functions, abilities exclusively by examining customer needs and their satisfaction. Satisfying customer needs at a high level leads to satisfaction in the long run resulting customer loyalty, reasonable activity and ultimately corporate income. Nevertheless in practice logical connection between factors are not as simple and coherent as that.

During the last decades, the researchers of customer satisfaction also have examined how to define systematically the effective satisfaction of customer needs and its elements applicable in models. The theories drawn did not manage to meet the requirements many times, or concerning their empirical studies the researchers often get various results, however, all of them agreed that customer satisfaction is a substantial part of the activity which needs to be examined continuously.

In the current study, we define a methodology of customer satisfaction assessment, a model that is capable of observing and forecasting the possible effects of our efforts on satisfaction. The essence of our model is to make non-financial performance levels measurable just like financial indicators even if they are impossible or just hard to measure considering the characteristics and psychological factors of satisfaction motivations. We wish to make and introduce such a model which besides financial indicators integrates those quality dimensions into management monitoring which possibly lead to satisfaction and loyalty what is meant to be the base for generating profit on the long term.
\end{abstract}

Keywords: satisfaction, index system, performance measurement, model, system-like approach

\section{PROBLEM STATEMENT AND METHOD - PERFORMANCE MEASUREMENT}

The problem of measuring performances is almost as old as the action of managing activities. The earlier measuring concepts were focusing on controlling activity progress and tracking financial processes. Implicitly performance measurement by financial indicators evolved early, and it has been an area of a deep research. Several measuring methods are known, these intend to determine performance in a simple or complex way. (e.g. BSC)

Many performance measurement systems interpret performance as tangible and measurable performances in financial terms, however, management literature underlines that performances being evaluated for the customers are based on some factors that cannot be measured directly or are subjective to them. It should be asked whether to create a particular performance measurement system concentrating not on measuring financial indicators, taking into account the psychological characteristics of consumer motivations, too.

We are rather aware that the problem is really serious if we also mean brand equity as well as customer loyalty and satisfaction as performance. At present literature is divergent concerning the interpretation and connection of terms such as brand equity, satisfaction and loyalty. Measuring customer satisfaction and dissatisfaction by subjective numbers can impose several further difficulties and dilemmas; companies often neglect this process but it is definitely a determining factor in customers' consumption behaviour and brand use. The need for constant raising customer service level and the widening service content of the products raise our attention to think over the dimensions of performance measurement.

The introduction of a performance evaluation system including not only financial indicators or the addition of the system existent both have a great importance during a 
company's operation since thanks to these the results support the company to maintain the results lasting long and to create brand loyal consumer groups.

Connection between performance and quality is also a dilemma, however obvious; its particular dimensions are hard to interpret - especially in case of services - though it is a determining element of value for the customer. "More and more people say that nowadays not the products that compete in the market but services and customer service performances."

Most indicators used these days are not capable of expressing clearly guidelines concerning customer satisfaction or dissatisfaction, moreover the question becomes harder, and satisfaction goes together with repurchase on condition of the performance that we supposedly would like to reach in real terms. Fortunately, dissatisfaction does not always cause brand switch, consequently if we measure or detect significant values, then we have the chance to intervene as well. Finally, we can state that indicator numbers based on merely finances cannot measure real performances, they are too aggregated, and they do not help during the interventions. This topic is extremely up-to-date because the growing market competition situation requires paying more and more attention than earlier to customer needs and this way own performances, "differentiation of performances". We need to meet several new challenges, that is why we are examining the results of performance function researchers.

\subsection{FUNCTIONS OF PERFORMANCE MEASUREMENT'S “NEW" MODEL}

In this study, we are looking for the answer how quality performance and customer service performances can be built into performance measurement and how it may expectedly lead to satisfaction. Using the supposed connection between brand loyalty and satisfaction we would like to create a multi-level system which provides management control points, and it is able to forecast positive or occasionally negative shifts. The performance system to be created includes several requirements, and at the same time its use gives us advantages as follows:

- Management (directing) functions: providing information continuously about connection and state between real and planned performances making intervention possible.

- Organizational function: setting normatives and their organisational communication which function as a foundation to goals and values important for the company meanwhile strengthening the organisation members' commitment, responsibility and accountability towards these goals.

- Technical function: providing out-company stakeholders information about organisation performance functioning as reference value and may also be represented as a guarantee element in a way.

\subsection{PROBLEMS OF PERFORMANCE MEASURING/INCREASING MODELS}

Increasing performance can work completely only if managers define tasks done by themselves and performances as well as customer values appeared with possible accidental faults. In the process of definition we should agree on specific quality parameters which can measure outputs earlier made in two ways:

- Concerning the quality of inner processes, or

- Concerning qualifications to meet goals, relating:

- organisational goals;

- customer goals.

During their analysis researchers face those problems which company managers can target after analysing study results: 
1. Methods analysing performances often turn focus point inside, and present customers as objects without will, or neglecting subjectivity influencing customer decisions. Some researchers draw our attention to the steps of customer decision-making; however, these steps are attained during performance measurement (or performance evaluation) because it is hard to build it into the set of objective indicators. Yet it is clear that the customer is eventually the one who can always evaluate exclusively the quality of outputs above from his particular view. To measure quality Johnson and Lewin put management solutions focused on increasing performance into four categories (Miller quotes, 1984).

- Target models which have a great emphasis on the process of determining organisational goals. The target model characterises the effective organisation setting its goals, determining activities necessary to reach these goals, then it delegates resources to these activities.

- System model supposes that a better organisational performance is resulting from an efficient organisation structure. Owing to organisation requirements and fast change of expectations it defines organisational efficiency as something to be measured in a difficult way and describes performance rather with the help of the combination of system characteristics. Instead of defining the term of efficiency they try to create a changing group what can lead to efficiency supposedly. (input variables, output variables, structural features, motivation, incentives)

- Decision systems put designing models in the foreground. Reaching effectiveness and efficiency is due to proper creation of designing and decision-making structure. Based on efficiency from an economic point of view an organisation creating the most output from given input or reaching a certain level of output with using the least input is said to be efficient. Or if an organisation is efficient, then resource allocation is Pareto optimal, and rearranging resources can produce new values only if decreasing values can be found elsewhere.

- Models based on management studies use different analysing methods depending on the features of the decision itself (mathematical programming, decision tree, simulations etc.). (Miller, 1984).

Like quality management concept, from the models above we can see that the customer's point of view is missing, or rather what is "appropriate" for him.

2. Concerning indicator numbers it is important to highlight that the values measured mean a little information to the user. The evaluation of performance can actually be interpreted as a contrast (in terms of time or benchmark) as well as the term of customer "requirement" is always relative.

3. A common problem of performance measurement that we should focus not only on measurable performances because customers do not only focus on this, or the management in the organization can act disincentive in making better performances on the long run, all in all they will be interested in reaching expected indicators.

4. Summing up performances faces an obstacle because there are several possible methods to measure given performances, furthermore the chance to combine is not straightforward, and the dimension of the individual numbers may be essentially different. There is a need for a theoretically established transparent and reproducible measurement and aggregation process which can provide only one or some complex numbers about how efficient the organisation is in turning inputs into outputs. This measurement and aggregation method should manage different output and input information, should not depend on the weights or prices established earlier, and should be able to manage qualitative data besides quantitative ones (Miller, 1984). As a principle, it is worth introducing the following: "We should measure anything that is measurable and turn anything immeasurable into measureable." 


\subsection{BRAND AS A COMPONENT OF VALUE}

Like products, services are labelled with a brand, which supports users in orientation, differentiation from other competitors. Usefulness and importance of branding: it helps to identify the service or the service provider, and to differentiate that from other competitor's service, and often contributes to the satisfaction of customers' psychological needs.

Brand equity is basically an economic category since it is the result of consumer demand and purchase; it creates continuous and excess cash flow that qualifies for the brand's "yield". Brand does not compose only of the identifiable aesthetic or symbolic characteristics (performances) of the product or service but also its positive or negative emotional effects, which grow in the customer after perceiving the factors, mentioned above in a subjective way.

All those associations that are present in the consumers' minds due to performances. As for the producer this brand equity means a new dimension of performance that should be observed, measured and corrected constantly.

\section{MATERIAL - VALUES AND PERFORMANCE IN THE CONSUMER'S EYES}

\subsection{PERFORMANCE (EFFICIENCY) DIMENSIONS}

Performance is defined as a measurable result of a particular activity. According to Neely, Gregory and Platts' (1995) definition, performance measurement is a process of measuring the efficiency and thriftness of a particular activity. Here we can find both sides of performance. The elements in literature are as follows:

- Added value: An excess value that is born in a particular process; or with the same amount of resources greater added value means greater performance.

- Quality: Service providers offer consumers a "package" that is why quality dimensions known at the products can only be used partly. There is a much greater importance of confidence, mouth tradition, habits in services. (Chikán, 2006)

- Efficiency: Ratio of output and expenditure. Different efficiency indicators can be drawn according to the type of expenditure such as complex indicators expressing the outcome of expenditures together. (Magyar Nagylexikon, 2002)

- Economy: Expenditures projected on a unit of the outcome reached, the product or services made, its amount given and evaluated in money. Economic indicators are usually defined as the quotient of the outcome and expenditure. (Janza, 1999)

- Outcome: Amount how much the real outcome matches the goals and expectations set. (Janza, 1999)

In case of corporate value creating processes we can only get information about efficiency and economy if we follow performance constantly. Evaluating information opens an opportunity to a continuous feedback including everyday operation control or strategy accomplishment control. (Becker-Turner-Varsányi-Virág, 2005)

\subsection{QUALITY AND VALUE}

People often use the terms 'efficient', 'valuable' and 'quality' with synonym meanings. They think that something of "good quality" and value at the same time (for instance customer value, usefulness, appropriateness) or effective (for instance economic, reaching goal, efficient, or appropriate etc.) and vice versa. In literature, we can find flexible explanations what the two terms really mean.

- Efficiency is usually determined in correlation with some output performance while quality is in connection with a standard or expectation. In case of services and often products fairness is added many times which brings relativity into judging. 
- The term quality coming from economy concentrates on relative quality and ensuring it, whose essential element is customer or user satisfaction which can be connected to customer value.

- A business activity's efficiency (efficiency) can be measured how much and what ratio the activity contributes to the profitable satisfaction of consumer's needs! Efficiency is the indicator of performance (Gyenge, 2008).

- The term of value is closely associated with the term of consumer's need (need at all). In the consumers' view value is an abstract term concerning the ratio of the need. Value is no other than the consumer's subjective opinion about appropriateness!

For consumers performance means value only if it has those features that help to satisfy a certain amount of their own need no matter whether this need is conscious, latent or not reasonable. The value or in other words quality dimensions of services and products may show essential differences.

\section{SATISFACTION = LOYALTY CONCEPT CRITICS}

It can be made possible that satisfaction affects loyalty on the long term (Mittal-Kumar-Tsiros, 1999), however, this relation is possibly non-linear what several authors can also underline (e.g. Mittal-Ross-Baldasare, 1998). If a product and a related service meet customer needs, then a high level satisfaction can take place, explains Jones-Sasser (1995) and he thinks that this high level satisfaction can also lead to a greater customer loyalty on the long run. Thus, literature is not unified.

Figure 1. Non-linear connection between customer satisfaction and income

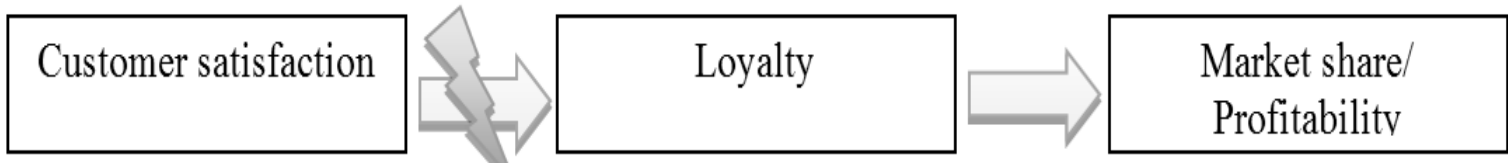

Source: own editing

Nevertheless, there is a close relation between customer loyalty and corporate profitability, which means this question, is still important for us. Experts suppose that a satisfied customer becomes loyal, and initiates repurchase while this is not always the case ideally. The consumer as an individual has a complex process of decision-making in which he considers several other determining factors when making decisions. Customer satisfaction is a necessary but not sufficient condition of loyalty.

- fairness of transaction,

- relative efficiency of transaction, characters of substituting offers

- satisfaction, attitudes towards suppliers,

- and customer (former) expectations.

In our opinion satisfaction is aimed at being measured since it is in relation with loyalty on the long term, and it is easier to measure as opposed to loyalty. In other words satisfaction may be interpreted as some kind of performance having more components. (See the model presented.)

According to particular studies consumers can be classified into at least three basic types based on the nature of their satisfaction (Stauss-Neuhaus, 1997) in the following way:

- stable satisfied ones who do not change brands and prefer old brands;

- challenging satified ones who have new needs, and if their needs are not completed, then they possibly leave;

- hopeless satisfied ones who feel that they cannot expect more, and that is why they should find a better offer, then they leave; 
The difference between qualities of services perceived and provided, and the management of this difference is an issue whose importance is out of question regarded customer retention. Evaluating a service the customer compares his expectation between the expected and appropriate service with the service perceived (experienced). That is not other than service quality.

As we can see in the following figure and according to some authors' approach, customer satisfaction can be rather interpreted as the customer's two-factor (bipolar) mind whose emotional resultant can express his real attitude. Except for the two extremities, satisfaction is rather a passive attitude than an active action motivation.

Figure 2: "Performance - attitude-behaviour" model

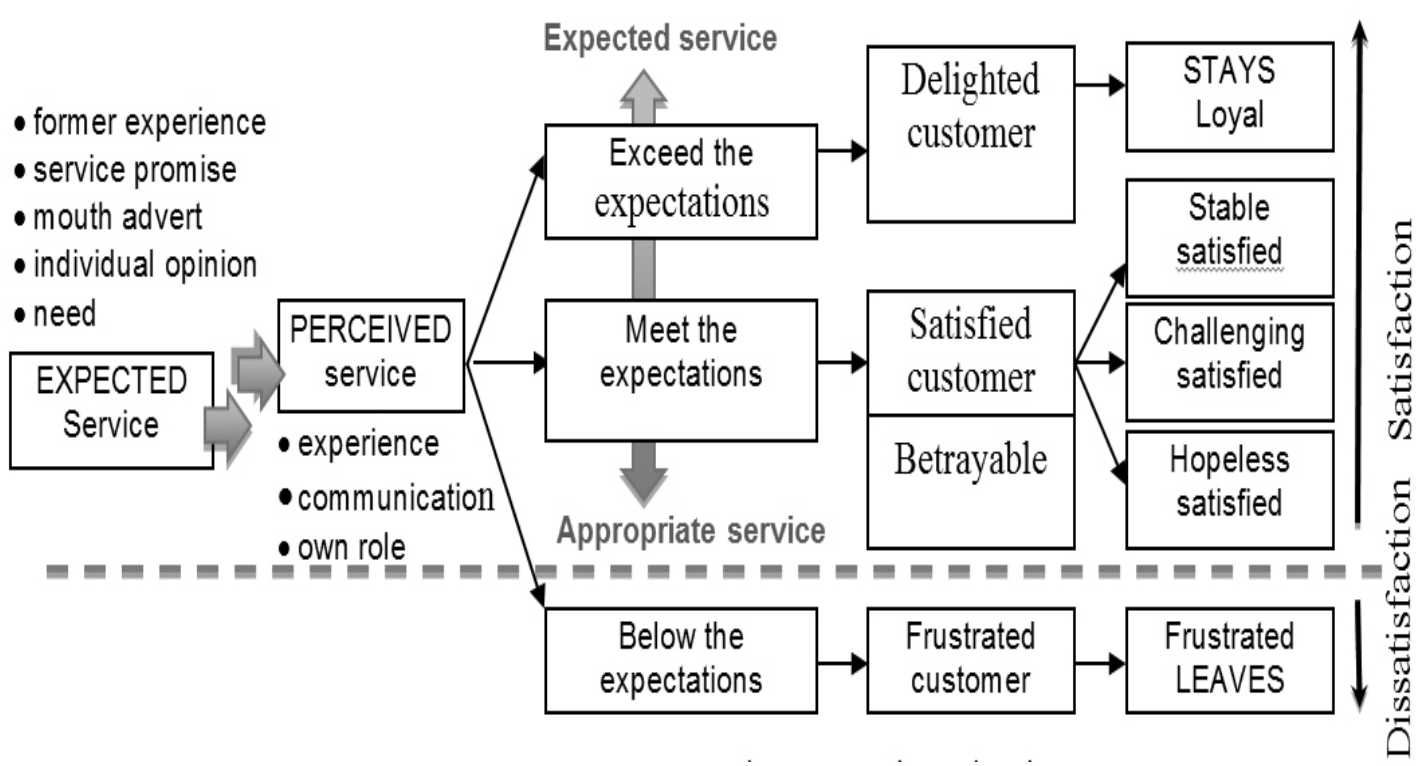

Source: own editing included some new parts and based on Stauss-Neuhaus, 1997

Herzberg's two-factor model theory (1968) explains that satisfaction itself does not depend on motivation exclusively (satisfied need) since the lack of factors affecting positively does not mean dissatisfaction automatically; the so-called "motivators" influence only satisfaction (e.g. expected result). At the same time the lack of other factors increases only dissatisfaction, these are called "hygiene factors" (e.g. safety, connection etc.).

Figure :- Different factors concerning satisfaction and dissatisfaction

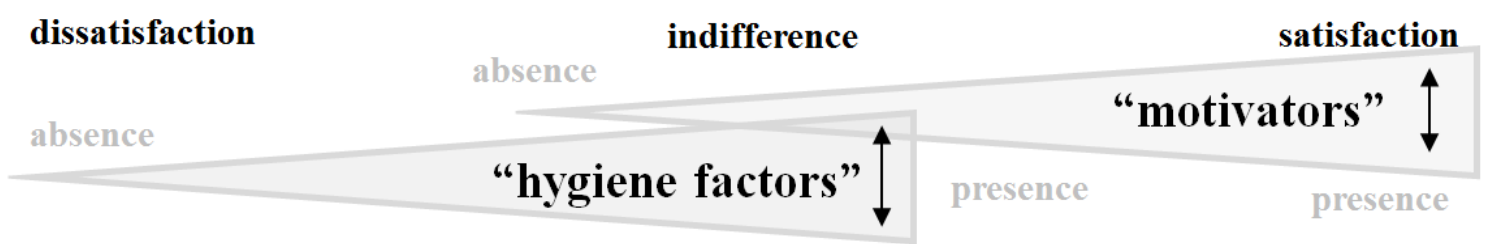

Source: own editing

Psychologically dissatisfaction is not the opposite of satisfaction but the lack of satisfaction, and this is true the other way round. Based on this we can have a categorisation of service elements with four types in the following way:

- Dissatisfaction elements: These factors, if they are inappropriate, make the client dissatisfied. However, they do not make him satisfied at all. (Generally in this case we 
should ensure the "guaranteed or qualifying level" reaching a yet acceptable and available with minimum cost but later it is not worth wasting additional energy on developing these elements.)

- Satisfaction elements: Unlike dissatisfaction elements, these elements should really be developed above the acceptable level because satisfaction will also increase proportionately to it at the same time. It is true that the minimum level will not lead to dissatisfaction either.

- Critical, or double elements: These are suitable for provoking both satisfaction and dissatisfaction. Speed of service is an example since fast service makes one satisfied and slow service makes him dissatisfied.

- Neutral elements: These factors have an effect on the ratio of satisfaction. For instance inner compatibility and connectivity technical factors important for the provider are not available for the clients in a normal case.

If we want to know whether the customer is satisfied or not, it is not enough to ask "Are you satisfied with the service?". Actually, the customers do not reply with "answers" rather with business decisions, leave or loyalty. Most of the customers do not express their negative attitude but they draw back instead. Because of these, it is practical to observe customer satisfaction; there are several further positive consequences (Muffatto-Panizzolo, 1995 and Fornell, 1992):

1. company's fame or image improves;

2. loyalty improves (Fornell);

3. more attention paid to consumer needs;

4. lower transaction cost;

5. price flexibility decreases (Fornell);

6. marketing cost decreases;

7. the cost of failure connected to a product/service decreases;

8. higher labour stability;

9. can mean great switching obstacle in relations.

\section{TWO-FOLD SATISFACTION INDEX SYSTEM - THE MODEL}

The two-fold satisfaction/dissatisfaction index concept is based on terms such as customer loyalty, satisfaction, brand equity, quality and performance (see Figure 4.)

The new model is based on human decision-making process since its complexity it can still be interpreted as a black box. The model creates measurement while it brings psychic factors into the dimensions of satisfaction and dissatisfaction. For instance, the customers often interpret service different from the way the suppliers think, and generally they would be more satisfied with a more reliable but lower level service than the present one.

Satisfaction and dissatisfaction form the two sides of the new model, and their amount is represented by grades on top of one another. We intended to create a comprehensive index system having a double dimension.

Based on the horizontal dimension, the double dimension of the factors acting on satisfaction and the factors acting on dissatisfaction can be separated. Meanwhile, based on the vertical dimension, the layers of the individual indicators form correction levels on top of each other (see Figure 4). 
Figure 4: Satisfaction and the recognizable service quality

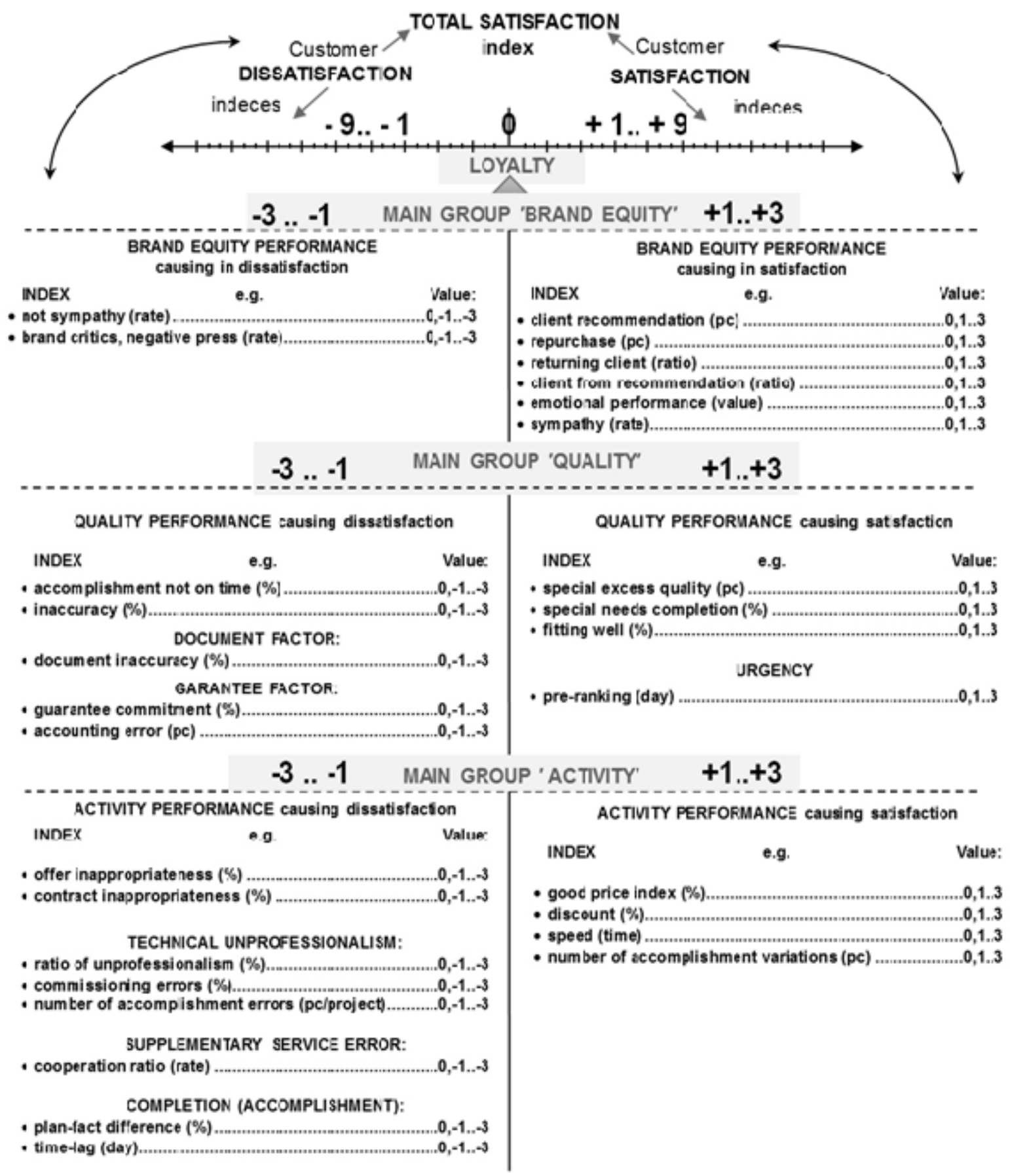

Source: own editing

Besides productivity indicators, the model integrates willingness to consume into formulating indicators as correction factors. To refine the final result we formed brand equity indicators as well. The model is able to make loyalty measurable, also establishes information concerning product development and answers important questions such as "How to intensify the customer's satisfaction in a way that loyalty should grow in him?"

Scoring in a unified system has a big advantage namely that we get a total value expressed in numbers (See Figure 4.) which can be cumulated in an aggregated way as well as by main groups. We cumulate indicators with values of identical scales (with the help of common denominator system). In the model, we qualify the indicators of different types or dimension 
by points between 0 and 3 according to the following verbal scale: ( 0 - no great importance in dissatisfaction or satisfaction; 1- considerable importance; 2- great importance; 3extraordinary importance). It is possible to match values with professional qualification of the indicator values. On the left hand side of the model in case of dissatisfaction indices the values have negative signs while on the right side in case of satisfaction indices the values have positive signs.

We may take the arithmetic mean of the main groups to have their total value. If we add up the means of the main groups, this will lead us to the final qualification; it is possible to compare (to add) the main indices of dissatisfaction and satisfaction to determine the cumulated satisfaction index whose value greater than zero shows the amount of "expected or perceived" satisfaction. Evaluating indicators can take place in cycles of quarters, and from these we can create timelines to track changes.

\section{EXPECTED RESULTS, FINDINGS, RECOMMENDATIONS}

Within the performance measurement and evaluation process getting to know, studying and forming, developing the factors acting on performance are crucial, as a sum up, managing performance. The three main processes of performance management are measuring and controlling performances, planning performances, and developing performances. (ChikánDemeter, 1999)

The model presented here is suitable to put the non-financial performance indicators acting on customer satisfaction in a unified framework, and keep them under continuous control, or integrate them into the everyday routine of the management activity.

Focusing on satisfaction and dissatisfaction factors may give better results and this will make customer loyalty and this way profitability on the long run. Nowadays performance management is every enterprise's primary interest.

\section{REFERENCES}

1. Anderson, E. W., Fornell, C., Lehmann, D. R. (1994): Customer Satisfaction, Market Share, and Profitability: Findings from Sweden, Journal of Marketing, Vol. 58, July 1994, pp. 53-66

2. Anderson, J. C.,Narus, J. A. (1998): Business Marketing: Understanding What Customers Value, Harvard Business Review, November-December 1998, pp. 53-65

3. Becker P., Turner A., Varsányi J., Virág M. (1995): Értékalapú stratégiák, A pénzügyi teljesítmény értékvezérelt menedzsmentje, Akadémiai Kiadó, Budapest.

4. Behara, Ravi S., Fontenot, Gwen F., Gresham, Alicia (1995): Customer Satisfaction Measurement and Analysis using six sigma, International Journal of Quality \& Reliability Management, Vol. 12 No. 3, 1995, pp. 9-18

5. Chikán A., Demeter K. (szerk.) (1999): Az értékteremtő folyamatok menedzsmentje, Budapesti Közgazdaságtudományi és Államigazgatási Egyetem, Aula Kiadó Kft., Bp.

6. David et al. (2008): Best value supply chains: A key competitive weapon for the 21st century. Business Horizons, Volume 51, Issue 3, May-June 2008, pp. 235-243

7. Duma L. (1999). Measurement of the performance of freight transport. Periodica Polytechnica Ser. Transportation Engineering, Vol. 26, No. 1-2., pp. 83-92

8. Gyenge B. - Buresch J. (2012): Elégedettségi mutató-rendszer használata a vállalat menedzsmentben, Budapest,.

9. Gyenge B. (2008): Termelés- és szolgáltatásmenedzsment Oktatási segédanyag, Szent István Egyetem, Gödöllö. 
10. Harrington (1991): Business process improvement: the breakthrough strategy for total quality, productivity, and competitiveness. McGraw-Hill, New York

11. Janza P. (1999): Hatékonyság és más teljesítményvizsgálatok módszerei, SALDO Pénzügyi Tanácsadó és Informatikai Rt., Budapest.

12. Kaplan, N., (1992): The balanced scorecard - measures that drive performance, Harvard Business Review, January-February, pp. 71-79

13. Keegan et al. (1989): Are your performance measures obsolete? Management Accounting (US) 70, pp. 45-50

14. Min et al. (2002): Supply chain modelling: past, present and future. Computers \& Industrial Engineering, Volume 43, Issues 1-2, 1 July 2002, pp. 231-249

15. Neely et al. (2001): The performance prism in practice, Measuring Business Excellence, Vol. 5 No. 2, pp. 6-12

16. Porter, M. (1985): Competitive advantage: Creating and sustaining superior performance, The Free Press, New York, NY, 1985

17. Swamidass (2000): Encyclopedia of production and manufacturing management, Kluwer Academic Publishers, Boston, MA, 2000

18. Székely Á. (2006): Teljesítménymérés és -értékelés a magyarországi víziközmü szektorban, PhD értekezés, Budapesti Corvinus Egyetem, Budapest.

19. Tangen (2004): Performance measurement: from philosophy to practice. International Journal of Productivity and Performance Management Vol. 53 No. 8, pp. 726-737

20. Van Hoek (2001): The contribution of performance measurement to the expansion of third party logistics alliances in the supply chain. International Journal of Operations \& Production Management Vol. 21 Issues 1-2, 2001, pp. 15-29

21. Véry Z.(2001): IT-SERVICE Információs szolgáltatások stratégiai irányítása, Bp.

22. Wimmer Á., Tarcali E., Pecze K. (2004): Teljesítménymérés a stratégia szolgálatában az iparági tapasztalatok, Corvinus Egyetem, Műhelytanulmányok, Bp. 